\title{
A new Leptographium species from the roots of declining Pinus sylvestris in Switzerland
}

\author{
S. Marincowitz ${ }^{1 *}$, T. A. Duong ${ }^{2}$, U. Heiniger ${ }^{3}$, B. D. Wingfield ${ }^{2}$, M. J. Wingfield ${ }^{1}$, Z. W. de Beer ${ }^{1}$ \\ ${ }^{1}$ Department of Microbiology and Plant Pathology, Forestry and Agricultural Biotechnology Institute (FABI), \\ University of Pretoria, Pretoria, South Africa \\ ${ }^{2}$ Department of Genetics, Forestry and Agricultural Biotechnology Institute (FABI), University of Pretoria, \\ Pretoria, South Africa \\ ${ }^{3}$ Swiss Federal Research Institute for Forest, Snow and Landscape WSL, CH-8903 Birmensdorf, Switzerland \\ *Correspondence: Seonju Marincowitz, Department of Microbiology and Plant Pathology, Forestry and \\ Agricultural Biotechnology Institute (FABI), University of Pretoria, Pretoria, South Africa. \\ Email: seonju.marincowitz@fabi.up.ac.za
}

\section{Summary}

Scots pine (Pinus sylvestris) trees have been declining in the Rhône valley, Switzerland, for almost three decades. In an assessment of the role of fungi in this syndrome, the dominant fungus isolated from stained roots was a Leptographium species, morphologically similar to the asexual state of Grosmannia serpens. We examined isolates of this fungus based on DNA sequences of four protein-coding genes including actin, $\beta$-tubulin, calmodulin and translation elongation factor-1 alpha. The results showed that they were of a distinct, undescribed taxon related to species in the Grosmannia serpens and G. wageneri complexes. The fungus, described here as Leptographium rhodanense sp. nov., resembles other species in the two species complexes morphologically, and most probably ecologically, as is suggested by the fact that it was isolated from stained pine roots.

\section{Introduction}

Since the early 1990s, a serious decline of Pinus sylvestris (Scots pine) resulting in high levels of mortality has occurred in the inner alpine Rhône valley (canton Valais) of Switzerland (Rigling \& Cherubini, 1999; Rigling et al., 2006). Various aspects of both abiotic and biotic stresses have been investigated as possible factors contributing to the decline (Wermelinger, Rigling, Schneider Mathis, \& Dobbertin, 2008). However, little is known about the possible roles of pathogenic fungi other than a few incidences of localized damage, which were not regarded as significant (Engesser, Forster, Meier, \& Odermatt, 2000). Heiniger, Theile, Rigling, and Rigling (2011) consequently considered the occurrence and possible role of pathogenic fungi in the decline.

The study of Heiniger et al. (2011) was conducted at two study sites, Salgesch and Stalden, in the inner alpine Rhône valley. More than 200 Scots pine trees ranging from 50 to 180 years old were sampled over a period of 5 years from May 2001 to February 2005. Many blue-stain fungi were isolated from various parts of the trees. Among these, a species 
with Leptographium-like conidiophores and dark, serpentine vegetative hyphae in culture, resembling those of Grosmannia serpens, was the most common fungus isolated from the roots (Heiniger et al., 2011). The aim of this study was to determine the identity and phylogenetic relationships of these isolates, and to consider their biology together with those of closely related species.

The taxonomy of the genera Leptographium and Grosmannia remains to be resolved in view of the one fungus = one name (1F1N) principles adopted in the Melbourne Code (Hawksworth, 2011; Hawksworth et al., 2011). Traditionally Leptographium was used for asexual species or the anamorphic state of "holomorphic" species, while Grosmannia was used to refer to species with known sexual states. Under the new Code, the older name Leptographium (Lagerberg, Lundberg, \& Melin, 1927) will take priority over Grosmannia (Goidànich, 1936). However, the type species of these two genera group in different species complexes, the generic boundaries of which need to be clarified with a thorough multigene analyses (De Beer \& Wingfield, 2013; Jacobs \& Wingfield, 2013). De Beer and Wingfield (2013) thus cautioned against unnecessary name changes that could result from the application of 1F1N principles before the generic boundaries have been resolved through a thorough and comprehensive multigene analyses. In this paper, we thus follow the recommendations by De Beer and Wingfield (2013) to ensure nomenclatural stability for the interim until the taxonomy on this group of fungi is clarified. The recommendations include that the names of all known species in Leptographium and Grosmannia are maintained and used as before and that new species outside the Grosmannia penicillata complex are described in Leptographium.

\section{Materials and Methods}

\subsection{Fungal isolates and morphology}

In total, 18 Grosmannia serpens-like isolates were collected by Heiniger et al. (2011) and these were included in the present study. Isolates have been maintained in the culture collection (CMW) of the Forestry and Agricultural Biotechnology Institute, University of Pretoria, South Africa. Ex-type isolates were deposited in the collection of the Centraalbureau voor Schimmelcultures (CBS), Utrecht, the Netherlands, and the dried cultures in the National Collection of Fungi (PREM), Roodeplaat, South Africa.

In order to describe morphological characteristics and to make comparisons with other species, isolates were grown on sterilized pine twigs in $2 \%$ water agar medium. Microscopy, growth in culture and tests for sensitivity to cycloheximide applied the methods described by Marincowitz, Duong, De Beer, and Wingfield (2015). Micromorphological features were described based on the standards suggested for Leptographium species in the monograph of Jacobs and Wingfield (2001).

\subsection{DNA extraction, PCR, DNA sequencing and phylogenetic analyses}

For initial identification, sequences of the internal transcribed spacer region 2 and partial large subunit (ITS2-LSU) were determined for all 18 isolates included in the study. To enable comparisons with the sequence data sets for the G. serpens complex in the study of Duong, 
De Beer, Wingfield, and Wingfield (2012), sequences of an additional four protein-coding genes, including parts of the actin (ACT), the $\beta$-tubulin ( $\beta T$ ), the translation elongation factor-1 alpha (TEF-1 $\alpha$ ) and the calmodulin (CAL) genes, were amplified and sequenced for a subset of five of the isolates. DNA extraction, primers, PCR and sequencing protocols were the same as that described by Duong et al. (2012).

Maximum likelihood (ML) and Bayesian inference (BI) analyses were performed on the aligned sequence data sets of the five gene regions (data not shown). A concatenated data set including sequences of the four protein-coding gene regions were then compiled. In both $\mathrm{ML}$ and $\mathrm{BI}$ analyses of these data sets, the general time reversible model with a gamma distribution of rates across sites $(G R T+G)$ was used. Maximum likelihood was conducted using raxmIGUI v1.3 (Silvestro \& Michalak, 2012). Ten runs of maximum likelihood searches followed by 1000 bootstrap replicates were conducted. Bayesian inference analyses were conducted using MrBayes 3.2 (Ronquist et al., 2012). Ten parallel runs with five million generations were conducted, trees were sampled every 10 th generation, and $25 \%$ of sampled trees were discarded as burn-in phase. Bayesian posterior probability values were calculated from the remaining trees.

\subsection{Mating-type PCR and ability to mate in culture}

Mating types of three L. wageneri varieties, G. alacris and Swiss Leptographium spp. were determined by PCR using mating-type primers and the PCR protocol developed for species of Leptographium sensu lato by Duong, De Beer, Wingfield, Eckhardt, and Wingfield (2015). In an attempt to obtain sexual structures, isolates were paired with each other as described by Grobbelaar, De Beer, Bloomer, Wingfield, and Wingfield (2010), but using pine twigs rather than hardwood twigs added to culture media.

\section{Results}

Analyses of the $\beta$-tubulin region showed that the 18 Swiss isolates considered in this study belonged to a single taxon that together with species in the $G$. serpens and $G$. wageneri complexes formed a monophyletic clade in Leptographium sensu lato (data not shown). ML and $\mathrm{BI}$ analyses of the concatenated data set of $A C T, \beta T, C A L$ and TEF- $1 \alpha$ gene regions resulted in trees with identical topologies in which the Swiss isolates formed a wellsupported monophyletic clade, clearly distinct from all known species in the $G$. serpens and G. wageneri complexes (Figure 1). 


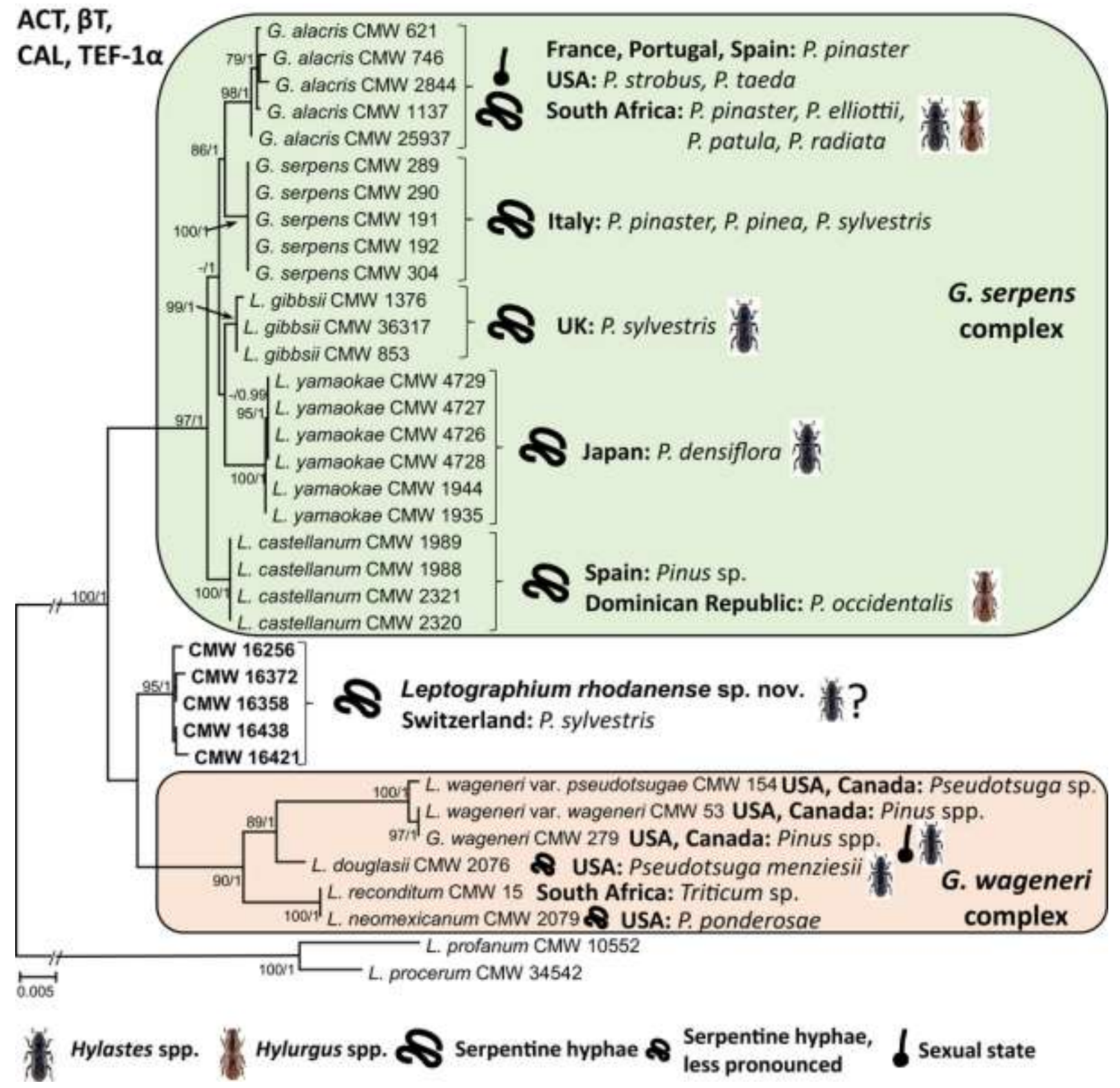

Figure 1. Maximum likelihood tree derived from analyses of concatanated dataset of ACT, $\beta T, C A L$ and TEF-1 $\alpha$ gene regions. Statistical supports (ML/BI) are indicated at nodes

Based on mating-type PCRs, Swiss isolates either contained the MAT1-1 or MAT1-2 idiomorph, but never both (Table 1). However, laboratory crosses with isolates of opposite mating type failed to produce the sexual state of the fungus. 
Table 1. Isolates of Leptographium rhodanense and isolates representing Grosmannia wageneri complex sequenced in this study

GeneBank Accession No.

$\begin{array}{lllllll}\text { Species } & \text { Isolate No. ITS2-LSU } & \text { ACT } & \beta T & \text { CAL } & \text { TEF-1 } \alpha\end{array}$

1.

Leptographium douglasii

Leptographium neomexicanum

Leptographium reconditum

Leptographium rhodanense $b$

Leptographium rhodanense a

Leptographium rhodanense $b$

Leptographium rhodanense a

Leptographium rhodanense b

Grosmannia wageneri

Leptographium wageneri var. pseudotsugae

Leptographium wageneri var. wageneri
CMW 2076

CMW 2079

CMW 15

CMW $16256=$ CBS

138286

CMW $16358=$ CBS

138285

CMW 16372

CMW 16421

cCMW $16438=$ CBS

138284

CMW 279

CMW 154

CMW 53
KY424502 KY424512 KY424522 KY424532

AY553382 KY424503 KY424513 KY424523 KY424533

$\begin{array}{lll}A F 343690 & \text { AY534931 } & \text { AY536177 }\end{array}$

=KY424539 KY424504 KY424514 KY424524 KY424534

=KY424539 KY424505 KY424515 KY424525 KY424535

=KY424539 KY424506 KY424516 KY424526 KY424536

$=$ KY424539 KY424507 KY424517 KY424527 KY424537

KY424539 KY424508 KY424518 KY424528 KY424538

KY424500 KY424510 KY424520 KY424530

AF343706 KY424499 KY424509 KY424519 KY424529

KY424501 KY424511 KY424521 KY424531

\footnotetext{
${ }^{a}$ mating-type MAT1-1.

${ }^{b}$ mating-type MAT1-2.

${ }^{c}$ ex-holotype.
}

CMW, the culture collection of the Forestry and Agricultural Biotechnology Institute (FABI), University of Pretoria, Pretoria, South Africa; CBS=CBS-KNAW, Utrecht, the Netherlands.

GenBank numbers in italic indicate sequences were not produced in this study.

Additional isolates and their mating type genes (confirmed to be $L$. rhodanense based on $\beta T$ sequences but not

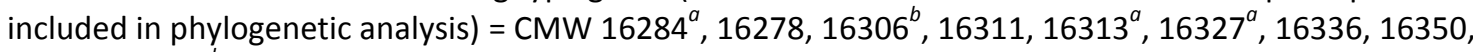
$16369^{a}, 16371^{b}, 16409,16418,16455$.

\subsection{Taxonomy}

Leptographium rhodanense Marinc., T.A. Duong, Z.W. de Beer \& M.J. Wingf. sp. nov. Figure 2. Mycobank MB819506. 


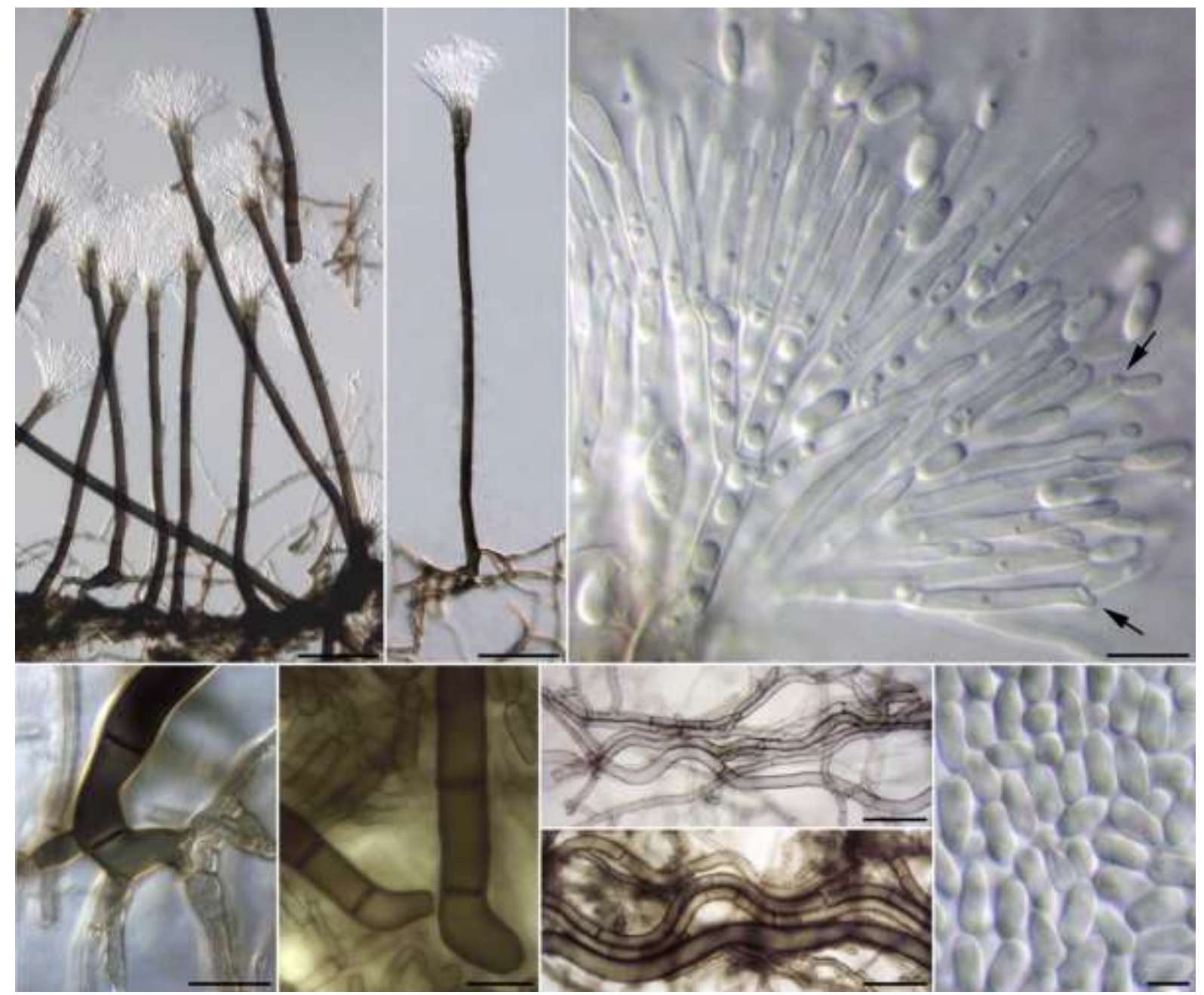

Figure 2. Microscopic images of Leptographium rhodanense (ex-holotype CBS $138284=$ CMW 16438) $(a, b)$ Conidiophores on 2\% MEA. (c) Conidiogenous apparatus showing blastic conidiogenesis (arrows). (d, e) Foot cells. (f) Young serpentine hyphae. (g) Aged serpentine hyphae. (h) Conidia. Scale bars: $a, b=50 \mu m ; c$, $\mathrm{d}=10 \mu \mathrm{m} ; \mathrm{e}, \mathrm{h}=5 \mu \mathrm{m} ; \mathrm{f}, \mathrm{g}=20 \mu \mathrm{m}$

Etymology: Name reflects the Rhône river that runs through the valley of Valais in Switzerland and where the samples were collected.

Description: Conidiophores single, upright, $270-500 \mu \mathrm{m}$ high from basal cell to conidiogenous cells. Stipes smooth, uniformly pigmented throughout, brown, slightly bulging at apex, 185-380 $\mu \mathrm{m}$ long, 7.8-13 $\mu \mathrm{m}$ wide, with 5-9 septa. Basal cells rhizoid to foot-like. Conidiogenous apparatus branched in 2-3(-4) tiers: primary branches in a whorl of 2-8, 14$27.5 \times 3.5-7.5 \mu \mathrm{m}$, secondary branches 9-20 × 2-4 $\mu \mathrm{m}$, tertiary branches 8.5-15 $\times 2-9 \mu \mathrm{m}$, quaternary branches divergent. Conidiogenous cells in a whorl of 3-5, cylindrical, gradually tapering towards the apex, often slightly constricted at the base, hyaline, smooth, tip showing sympodial growth, (10-)14-15(-19) $\times(1-) 2 \mu \mathrm{m}$. Conidia blastic, ellipsoidal, gradually tapering to truncated base, hyaline, $(4-) 5(-7) \times 2(-3) \mu \mathrm{m}$. Serpentine hyphae darker and wider than ordinary vegetative hyphae, 7.5-17 $\mu \mathrm{m}$ wide. Vegetative hyphae constricted at septum, pale brown becoming dark pigmented with age, 2.5-4 $\mu \mathrm{m}$ wide, foremost hyphae growing curved, not straight. Colonies with optimum growth at $20-25^{\circ} \mathrm{C}$ in the dark, reaching $78 \mathrm{~mm}$ in 4 days at $20^{\circ} \mathrm{C}$, translucent, inner circle $40 \mathrm{~mm}$ olivaceous 
brown, mycelium flat, rarely aerial, edges nearly smooth, no effect on medium, fertile. The addition of cycloheximide showed $27 \%$ reduction in growth area at $20^{\circ} \mathrm{C}$.

Habitat: roots of Pinus sylvestris.

Distribution area: Switzerland.

Holotype: Switzerland, canton Valais, Stalden, root of Pinus sylvestris, May 2004, U. Heiniger, holotype PREM 61102 (dried culture of CBS 138284), ex-holotype CBS 138284 = CMW 16438.

Additional specimens examined: Switzerland, canton Valais, Stalden, root of Pinus sylvestris, Feb 2004, U. Heiniger, CBS 138285 = CMW 16358; Salgesch, root of Pinus sylvestris, May 2002, U. Heiniger, CBS 138286 = CMW 16256.

\section{Discussion}

Results of this study have shown that a Leptographium sp. consistently isolated from the roots of dying $P$. sylvestris trees in Switzerland represents a new taxon described here as L. rhodanense. The distinctive serpentine hyphae produced by this species in culture resemble those of species in the $G$. serpens complex and they were less similar to those found in some species in the related G. wageneri complex which have less pronounced serpentine hyphae. While some Leptographium spp. can be identified using the dimensions of their conidiogenous apparatuses and conidia (Jacobs \& Wingfield, 2001), this is not possible for species in the $G$. serpens complex. DNA sequence comparisons are thus necessary to distinguish species in this group (Duong et al., 2012) and these showed clearly that the Swiss isolates represent a novel taxon.

Mating-type PCRs confirmed the presence of both mating types among isolates of L. rhodanense and this shows that the species is heterothallic. It was, however, not possible to confirm this based on laboratory tests in culture. A heterothallic state in L. rhodanense is consistent with the fact that members of the $G$. serpens and $G$. wageneri complexes are known to be heterothallic (Duong, De Beer, Wingfield, \& Wingfield, 2016).

All species in the $G$. serpens complex and the majority of those in the $G$. wageneri complex occur on Pinus spp. and this is consistent with the ecology of $L$. rhodanense. The only exceptions are L. wageneri var. pseudotsugae and L. douglasii that occur on Pseudotsuga (Wingfield, Harrington, \& Crous, 1994; Zambino \& Harrington, 1989) and L. reconditum that was described from the rhizosphere of wheat (Jooste, 1978). Leptographium rhodanense was isolated from stained and diseased roots. From the same trees that were the source of isolates for this study, Hylastes spp. were the most common insects isolated from roots (unpublished data, Heiniger et al., 2011). Although no attempts were made to isolate fungi from these insects nor their galleries (Heiniger, pers. comm.), it seems probable that a species in this genus is a vector of the fungus. This would be consistent with the fact that many root-infecting Leptographium spp. are associated with Hylastes spp. (Goheen \& Cobb, 1978; Kirisits, 2004; Masuya, Yamaoka, Kaneko, \& Yamaura, 2009; Wingfield, Capretti, \& MacKenzie, 1988; Wingfield \& Knox-Davies, 1980). However, isolations of this fungus from 
the insects as well as from their galleries should be undertaken to establish the nature of this relationship with confidence.

Heiniger et al. (2011) observed that the occurrence of blue-stain fungi was positively related to the crown transparency of trees, which was used as a measure of tree health. They also noted that a high number of the roots of moderately healthy trees were infected with L. rhodanense. From these observations, they suggested the blue-stain fungi including L. rhodanense could, together with their insect vectors, play a role in the decline of Scots pine in Rhône Valley. It is unlikely that $L$. rhodanense is a primary pathogen as is the case with the three varieties of $L$. wageneri varieties (Harrington \& Cobb, 1988). However, the fungus could contribute to the decline of the trees where its insect vectors have infested the roots and as has been shown for G. serpens (Goidànich, 1936) and G. alacris (Wingfield \& Knox-Davies, 1980; Wingfield \& Marasas, 1980; Zhou, De Beer, Wingfield, \& Wingfield, 2002).

\section{Acknowledgements}

Financial support for this work was provided by members of the Tree Protection Cooperative Programme (TPCP) and the Department of Science and Technology (DST)-National Science Foundation (NRF) Centre of Excellence in Tree Health Biotechnology (CTHB). We appreciate the assistance of Dr Hugh Glen for the Latin name for the new species.

\section{Funding information}

the Tree Protection Co-operative Programme (TPCP); the Department of Science and Technology (DST)-National Science Foundation (NRF) Centre of Excellence in Tree Health Biotechnology (CTHB)

\section{References}

De Beer, Z. W., \& Wingfield, M. J. (2013). Emerging lineages in the Ophiostomatales. In K. A. Seifert, Z. W. De Beer, \& M. J. Wingfield (Eds.), The ophiostomatoid fungi: Expanding frontiers (pp. 21-46). Centraalbureau voor Schimmelcultures (CBS), Utrecht, The Netherlands: CBS Biodiversity Series.

Duong, T. A., De Beer, Z. W., Wingfield, B. D., Eckhardt, L. G., \& Wingfield, M. J. (2015). Microsatellite and mating type markers reveal unexpected patterns of genetic diversity in the pine root-infecting fungus Grosmannia alacris. Plant Pathology, 64, 235-242.

Duong, T. A., De Beer, Z. W., Wingfield, B. D., \& Wingfield, M. J. (2012). Phylogeny and taxonomy of species in the Grosmannia serpens complex. Mycologia, 104, 715-732.

Duong, T. A., De Beer, Z. W., Wingfield, B. D., \& Wingfield, M. J. (2016). Mating type markers reveal high levels of heterothallism in Leptographium sensu lato. Fungal Biology, 120, 538-546.

Engesser, R. M., Forster, B., Meier, F., \& Odermatt, O. (2000). Forstschutzsituation 1999 in der Schweiz. (Forest health situation in Switzerland in 1999). AFZ/Der Wald, 7, 360-361.

Goheen, D. J., \& Cobb, F. W. (1978). Occurrence of Verticicladiella wagenerii and its perfect state, Ceratocystis wageneri sp. nov., in insect galleries. Phytopathology, 68, 1192-1195. 
Goidànich, G. (1936). Il genere di Ascomiceti 'Grosmannia' G. Goid. Bollettino della Stazione di Patología Vegetale di Roma, 16, 26-40.

Grobbelaar, J. W., De Beer, Z. W., Bloomer, P., Wingfield, M. J., \& Wingfield, B. D. (2010). Ophiostoma tsotsi sp. nov., a wound-infesting fungus of hardwood trees in Africa. Mycopathologia, 169, 413-423.

Harrington, T. C., \& Cobb, F. W. (1988). Leptographium root diseases on conifers. St. Paul, Minnesota: APS Press.

Hawksworth, D. L. (2011). A new dawn for the naming of fungi: Impacts of decisions made in Melbourne in July 2011 on the future publication and regulation of fungal names. MycoKeys, 1, 720.

Hawksworth, D. L., Crous, P. W., Redhead, S. A., Reynolds, D. R., Samson, R. A., Seifert, K. A., ... Zhang, N. (2011). The Amsterdam Declaration on Fungal Nomenclature. IMA Fungus, 2, 105-112.

Heiniger, U., Theile, F., Rigling, A., \& Rigling, D. (2011). Blue-stain infections in roots, stems and branches of declining Pinus sylvestris trees in a dry inner alpine valley in Switzerland. Forest Pathology, 41, 501-509.

Jacobs, K., \& Wingfield, M. J. (2001). Leptographium species: Tree pathogens, insect associates, and agents of blue-stain. St. Paul, Minnesota: APS Press.

Jacobs, K., \& Wingfield, M. J. (2013). An overview of Leptographium and Grosmannia. In K. A. Seifert, Z. W. De Beer \& M. J. Wingfield (Eds.), The ophiostomatoid fungi: Expanding frontiers (pp. 47-56). CBS, Utrecht, The Netherlands: CBS Biodiversity Series.

Jooste, W. J. (1978). Leptographium reconditum sp. nov. and observations on conidiogenesis in Verticicladiella. Transactions of the British Mycological Society, 70, 152-155.

Kirisits, T. (2004). Fungal associates of European bark beetles with special emphasis on the ophiostomatoid fungi. In F. Lieutier, K. R. Day, A. Battisti, J.-C. Grégoire, \& H. F. Evans (Eds.), Bark and wood boring insects in living trees in Europe, a synthesis (pp. 181-235). Netherlands: Springer.

Lagerberg, T., Lundberg, G., \& Melin, E. (1927). Biological and practical researches into blueing in pine and spruce. Svenska Skogsvårdsföreningens Tidskrift, 25, 145-272.

Marincowitz, S., Duong, T. A., De Beer, Z. W., \& Wingfield, M. J. (2015). Cornuvesica: A little known genus in the Ceratocystidaceae including unexpected new species. Fungal Biology, 119, 615-630.

Masuya, H., Yamaoka, Y., Kaneko, S., \& Yamaura, Y. (2009). Ophiostomatoid fungi isolated from Japanese red pine and their relationships with bark beetles. Mycoscience, 50, 212-223.

Rigling, A., \& Cherubini, P. (1999). Wieso sterben die Waldföhren im "Telwald" bei Visp? Eine Zusammenfassung bisheriger Studien und eine dendroökologische Untersuchung. (Why are Scots pines dying in the 'Telwald' near Visp? A summary of studies and dendroecological analyses). Schweizerische Zeitschrift für Forstwesen, 150, 113-131. 
Rigling, A., Dobbertin, M., Bürgi, M., Feldmeier-Christe, E., Gimmi, U., Ginzler, C., ... Wohlgemuth, T. (2006). Baumartenwechsel in den Walliser Waldföhrenwäldern. (Tree species change in the Scots pine forests of Valais). In T. Wohlgemuth (Ed.), Wald und Klimawandel (Forest and global change) (pp. 23-33). Eidg. Forschungsanstalt WSL: Forum für Wissen.

Ronquist, F., Teslenko, M., Van der Mark, P., Ayres, D. L., Darling, A., Höhna, S., ... Huelsenback, J. P. (2012). MrBayes 3.2: Efficient Bayesian phylogenetic inference and model choice across a large model space. Systematic Biology, 61, 539-542.

Silvestro, D., \& Michalak, I. (2012). raxmIGUI: A graphical front-end for RAxML. Organisms Diversity and Evolution, 12, 335-337.

Wermelinger, B., Rigling, A., Schneider Mathis, D., \& Dobbertin, M. (2008). Assessing the role of bark-and wood-boring insects in the decline of Scots pine (Pinus sy/vestris) in the Swiss Rhone valley. Ecological Entomology, 33, 1-11.

Wingfield, M. J., Capretti, P., \& MacKenzie, M. (1988). Leptographium spp. as root pathogens of conifers. An international perspective. In T. C. Harrington \& F. W. Cobb Jr (Eds.), Leptographium root diseases on conifers (pp. 113-149). St. Paul, Minnesota: APS Press.

Wingfield, M. J., Harrington, T. C., \& Crous, P. W. (1994). Three new Leptographium species associated with conifer roots in the United States. Canadian Journal of Botany, 72, 227-238.

Wingfield, M. J., \& Knox-Davies, P. S. (1980). Root disease, associated with Verticicladiella alacris, of pines in South Africa. Plant Disease, 64, 569-571.

Wingfield, M. J., \& Marasas, W. F. O. (1980). Verticicladiella alacris sp. nov., associated with a root disease of pines in South Africa. Transactions of the British Mycological Society, 75, 21-28.

Zambino, P. J., \& Harrington, T. C. (1989). Isozyme variation within and among host-specialized varieties of Leptographium wageneri. Mycologia, 81, 122-133.

Zhou, X. D., De Beer, Z. W., Wingfield, B. D., \& Wingfield, M. J. (2002). Infection sequence and pathogenicity of Ophiostoma ips, Leptographium serpens and L. lundbergii to pines in South Africa. Fungal Diversity, 10, 229-240. 